\title{
Article/Artigo
}

\section{Is severe visceral leishmaniasis a systemic inflammatory response syndrome? - A case control study}

\author{
A leishmaniose visceral grave é uma síndrome da resposta inflamatória sistêmica? - Um estudo \\ caso-controle
}

\section{Carlos Henrique Nery Costa ${ }^{1,2}$, Guilherme Loureiro Werneck ${ }^{3,4}$, Dorcas Lamounier Costa ${ }^{5,6}$, Thiago Ayres Holanda , Guilherme Brasileiro Aguiar ${ }^{7}$, Aline Santos Carvalho ${ }^{7}$, Janaína Costa Cavalcanti ${ }^{7}$ and Loryenne Santos Santos ${ }^{7}$}

\begin{abstract}
Introduction: The objective of the study is to identify the main risk factors for death by New World visceral leishmaniasis and establish a coherent pathogenic substrate of severe disease based on clinical findings. Methods: Seventy-six deceased inpatients and 320 successfully treated inpatients with VL were studied in a case control study. Results: Bacterial infection and bleeding were mutually exclusive events leading to death. Five risk factors were unique for death by bacterial infection (malnutrition, pulmonary rales, severe anemia, severe absolute neutropenia and higher neutrophil count), while another six were unique for death by bleeding (jaundice, severe relative neutropenia, severe thrombocytopenia, liver injury, kidney failure, higher bone marrow parasite load). Bacterial infection, bleeding, severe anemia, diarrhea, dyspnea, edema, jaundice and bone marrow parasite load were the main syndromes of visceral leishmaniasis among successfully treated patients. Conclusions: The data support the idea that bacterial infections are due to immune paralysis. Broad organ and system involvement is plausibly due to the high production of proinflammatory cytokines, whose actions fit well with visceral leishmaniasis. The syndromes and causative mediators are typical of a slowly developing systemic inflammatory response syndrome.
\end{abstract}

Key-words: Visceral leishmaniasis. Kala-azar. Severe inflammatory response syndrome. AIDS. Bleeding.

\section{RESUMO}

Introdução: $\mathrm{O}$ objetivo do estudo foi identificar os principais fatores de risco para morte na leishmaniose visceral do Novo Mundo e estabelecer um substrato patogênico baseado nos achados clínicos coerente para doença grave. Métodos: Em um estudo caso-controle, foram estudados 76 pacientes internados que faleceram e 320 pacientes internados tratados com sucesso. Resultados: Infecção bacteriana e sangramento foram eventos que levaram à morte, mutuamente exclusivos. Cinco fatores de risco foram únicos para morte por infecção bacteriana (desnutrição, estertores pulmonares, anemia grave, neutropenia absoluta grave e número de leucócitos aumentados), enquanto outros seis foram exclusivos para morte por sangramento (icterícia, neutropenia relativa grave, trombocitopenia grave, lesão hepática, insuficiência renal, maior carga de parasitas na medula óssea). Entre os pacientes tratados com sucesso, as principais síndromes de leishmaniose visceral foram infecções bacterianas, sangramento, anemia grave, diarreia, dispneia, edema, icterícia e carga de parasitas na medula óssea. Conclusões: Os dados apoiam a ideia de que as infecções bacterianas são secundárias a imunoparalisia. $\mathrm{O}$ amplo envolvimento de órgãos e sistemas é de forma plausível devido a elevada produção de citocinas pró-inflamatórias, cujas ações se encaixam com a leishmaniose visceral. As síndromes e os mediadores causais são típicos da síndrome de resposta inflamatória sistêmica, desenrolando-se lentamente.

Palavras-chaves: Leishmaniose visceral. Calazar. Síndrome da resposta inflamatória sistêmica. AIDS. Sangramento.

1. Laboratory of Leishmaniasis, Tropical Diseases Institute Natan Portella, Teresina, PI, Brazil. 2. Department of Community Medicine, Federal University of Piauí, Teresina, PI, Brazil. 3. National School of Public Health Sérgio Arouca, Oswaldo Cruz Foundation, Rio de Janeiro, RJ, Brazil. 4. Federal University of Rio de Janeiro, Rio de Janeiro, RJ, Brazil. 5. Federal University of Minas Gerais, Belo Horizonte, MG, Brazil. 6. Department of Mother and Child Health, Federal University of Piauí, Teresina, PI, Brazil. 7. Federal University of Piauí, Teresina, PI, Brazil.

Partially presented at the $13^{\text {th }}$ International Congress of Immunology, Rio de Janeiro, August 21-27, 2007.

Address to: Dr. Carlos Henrique Nery Costa. Instituto de Doenças Tropicais Natan Portella. R. Artur de Vasconcelos 151-Sul, 64001-450 Teresina, PI, Brasil.

Tel: 5586 3221-3413; Fax: 5586 3222-3248

e-mail: chncosta@gmail.com

Received in $10 / 11 / 2009$

Accepted in 16/04/2010

\section{INTRODUCTION}

Visceral leishmaniasis (VL), or kala-azar, is a parasitic disease endemictomanytemperate and tropical countries. The clinical picture consists of a protracted course of fever, pallor, wasting, hepatosplenomegaly and pancytopenia. Thousands of deaths have occurred in lethal epidemics and the disease is an important opportunistic infection in patients with $\mathrm{HIV}^{1}$. The agent of the anthroponotic disease is Leishmania donovani on the Indian subcontinent and in East Africa. Leishmania infantum (=Leishmania chagasi) has a zoonotic cycle involving humans, dogs and wild canines in Asia, the Mediterranean area and the New World. The organisms are obligate intracellular protozoa, mostly found in the spleen, bone marrow, liver and lymph nodes, and the disease is transmitted by sand flies. Treatment is based on pentavalent antimonials and amphotericin $\mathrm{B}^{1}$.

There is no known effective strategy to reduce the transmission of VL, although vaccines are still a hope. Even with treatment, 5-10\% of patients die ${ }^{2}$. In Brazil, urbanization of the disease has been reported since the early 1980s, progressively spreading throughout the country. VL leads to about 240 deaths each year in Brazil, a number much higher than that of malaria and dengue hemorrhagic fever ${ }^{3}$. Guidelines for managing severe disease have been developed ${ }^{4}$, but fatality rates remain high. Previous studies demonstrated that extremes of age, malnutrition, length of fever and the presence of vomiting, diarrhea, severe anemia, jaundice, enlarged spleen and thrombocytopenia are risk factors for death ${ }^{2,5-7}$. Although bacterial infections and bleeding account for most fatal complications ${ }^{5,7-9}$, little is known about their pathogenic pathways. However, disseminated intravascular coagulation ${ }^{10}$, liver failure ${ }^{11}$ and hemophagocytic syndrome have been implicated.

A case-control study was therefore designed to investigate the nature of VL deaths, especially those associated with bacterial infections and hemorrhage. The independence of these two outcomes was evaluated, the risk factors associated with them were 
listed, and a coherent network of clinical and laboratory related data was identified and discussed so that a logical hypothesis explaining the pathophysiology of death from VL could be formulated.

\section{METHODS}

\section{Study population}

At a referral hospital for infectious diseases in Teresina, northeastern Brazil, medical records from deceased inpatients and survivors with VL from 1996 to 2005 were randomly selected. Only patients with typical symptoms plus a positive direct bone marrow (BM) smear, BM culture or indirect immunofluorescence test (Biomanguinhos, Rio de Janeiro, Brazil) at dilution $\geq 1: 80$ were included. Records without proper data entries were excluded. The Institutional Review Board of the Natan Portella Institute of Tropical Diseases (Instituto de Doenças Tropicais) approved this retrospective medical record review.

\section{Exposure and outcome measurement}

Only signs and symptoms present at hospital admission were considered, as well as the initial laboratory results. Weighing of patients was infrequently performed. The weight-for-age $z$-score was calculated; patients $\leq 18$ years-old were classified as malnourished if the $z$-score was less than -1.95 . The presence of bacterial infection was determined mostly on clinical and radiological grounds and a positive culture was not required. A positive BM smear defined higher BM parasite load. The records of deceased patients with VL were independently reviewed by two observers to determine the causes of death.

\section{Data analysis}

Risk factors for all deaths were identified by univariate and multivariate logistic regression and associations between variables were expressed as odds ratios (OR) and respective $95 \%$ confidence intervals (95\% CI). Multivariate analysis was performed using a step-by-step backward selection procedure and variables remained in the final model if the association with the outcome was significant at the $5 \%$ level.

The binomial test was applied to check whether the number of dead patients with both bacterial infection and bleeding was independent. Comparisons of the ORs between variables associated with death by bacterial infection and by hemorrhage were performed using seemingly unrelated estimation procedures. Among survivors, risk factors for the main syndromes were investigated and Spearman correlation coefficients between the quantitative laboratory tests were calculated. Analysis were conducted in Stata 9.0 (SataCorp, College Station, TX).

\section{Ethical}

The Ethical Review Board of Federal University of Piauí granted approval to the study.

\section{RESULTS}

\section{Study population}

Seventy-six deceased patients (cases) and 320 survivors (controls) were studied. Sixty-eight were male. Twelve (16\%) were under one yearold, 118 (30\%) were aged 1-4 years-old, and 216 (54\%) were less than 15 years-old. Nine (2.3\%) patients were HIV-positive (Table 1).

\section{Causes of death}

Thirty-one patients died from severe bacterial infection, 29 died from bleeding and three died with simultaneous hemorrhage and evidence of infection. The observed number of concurrent deaths by bleeding and infection was significantly less than the expected number (EN) of deaths by the two events if they were statistically independent $(\mathrm{EN}=14.3, \mathrm{p}<0.001)$ (Table 2).

\section{Symptoms and signs associated with death by all causes}

In the univariate analysis, the risk of death was higher among infants $<1$ year and among patients $>40$ years-old. Since only 60 persons had their weight measured, the well-known effect of malnutrition on kala-azar mortality could not be determined with certainty. However, malnutrition was remarkably associated with death by bacterial infection $(\mathrm{OR}=6.2)$. The following variables were associated with death: vomiting, diarrhea, respiratory distress (dyspnea and pulmonary rales), edema, severe anemia, hepatic involvement (jaundice and elevated alanine amino transferase), kidney syndromes (kidney failure and proteinuria), neutrophil count abnormalities (absolute number $\geq 5,000 / \mathrm{mm}^{3}$ and relative count $\leq 10 \%)$, severe thrombocytopenia $\left(\leq 50,000 / \mathrm{mm}^{3}\right)$, low serum albumin, high BM parasite load, history of any sign of hemorrhage, bacterial infection and HIV/AIDS (Table 3).

The following variables were associated with death by VL in the multivariate analysis: age $<1$ year-old $(\mathrm{OR}=4.1 ; \mathrm{CI}: 1.6,10.6)$; age $>40$ years-old $(\mathrm{OR}=7.4$; CI: 2.9, 18.9); vomiting $(\mathrm{OR}=3.9$; $\mathrm{CI}: 1.9,8.2)$;

TABLE 1 - Overall characteristics of the patients with visceral leishmaniasis.

\begin{tabular}{lc}
\hline Characteristic & $\frac{\text { Patients }}{\mathbf{n}(\%)}$ \\
\hline Cases and controls & $320(81.0)$ \\
$\quad$ survivors & $76(19.0)$ \\
$\quad$ dead & \\
\hline Sex & $268(68.0)$ \\
male & $128(32.0)$ \\
female & \\
\hline Age-groups (years) & $49(12.0)$ \\
$<1$ & $118(30.0)$ \\
$1<5$ & $49(12.0)$ \\
$5<15$ & $118(30.0)$ \\
$15<40$ & $61(15.0)$ \\
$\geq 40$ & \\
\hline HIV infection & $9(2.3)$ \\
yes & $387(97.7)$ \\
no & $396(100.0)$ \\
\hline total &
\end{tabular}

TABLE 2 - Causes of death attributed to 76 patients with visceral leishmaniasis.

\begin{tabular}{lr}
\hline Cause of death & $\frac{\text { Patients }}{\mathbf{n}(\%)}$ \\
\hline Suspected bacterial infection & $31(41.0)$ \\
Bleeding & $29(38.0)$ \\
Infection and bleeding & $3(4.0)$ \\
Respiratory failure & $4(5.0)$ \\
Liver failure & $2(3.0)$ \\
Kidney failure & $1(1.0)$ \\
Not determined & $6(8.0)$ \\
\hline Total & $\mathbf{7 6 ( 1 0 0 . 0 )}$ \\
\hline
\end{tabular}


history of bleeding (OR = 4.2; CI: 1.9, 9.4); dyspnea (OR=4.3; CI: 2.1, 9.1); jaundice (OR: 2.7; CI: 1.1, 5.0); edema (OR = 2.4, CI: 1.1, 5.0); HIV infection ( $\mathrm{OR}=19.0$; CI: 1.7, 211.3); leukocytes $\geq 7,000$ / $\mathrm{mm}^{3}(\mathrm{OR}=2.8$; CI: 1.1, 7.1); neutrophils $<10 \%(\mathrm{OR}=5.2$; CI: 1.1, $25.2)$; and neutrophils $>70 \%(\mathrm{OR}=3.5$; CI: $1.3,9.1)$.

Symptoms and signs associated with death by bacterial infection and by bleeding disorders in univariate analysis

Variables similarly associated with death by bacterial infection and by hemorrhage: age $<1$ year-old and $>40$ years-old, vomiting, diarrhea, dyspnea, edema, any bleeding, HIV/AIDS and relative neutrophilia $>70 \%$. Variables associated with death by bacterial infection but not by hemorrhage: pulmonary rales, bacterial infection at admission, severe anemia, severe absolute neutropenia and higher neutrophil count. Variables associated with death by hemorrhage but not by bacterial infection: jaundice, severe relative neutropenia, liver injury, kidney failure, severe thrombocytopenia and high BM parasite load (Table 4).

\section{Multivariate analysis of death by bacterial infection and by hemorrhage}

Bacterial infection: vomiting ( $\mathrm{OR}=3.5$; $\mathrm{CI}: 1.5,8.5)$; dyspnea $(\mathrm{OR}=6.1$; CI: 2.5, 15.1); bleeding $(\mathrm{OR}=3.1$; CI: 1.2, 7.9); HIV/AIDS (OR = 15.5; CI: 1.1, 219.6); and relative neutrophil count $<10 \%(\mathrm{OR}=7.0$; CI: $1.2,41.0)$ or $>70 \%(\mathrm{OR}=6.6$; CI: 2.3, 18.7). Bacterial infections were not included in the model. Hemorrhage: age $<1$ year-old $(\mathrm{OR}=4.9$; CI: $1.3,19.1)$ and $>40$ years-old $(\mathrm{OR}=13.8 ; \mathrm{CI}: 3.7,50.9)$; vomiting $(\mathrm{OR}=4.2$; CI: 1.4, 12.4); diarrhea (OR=4.9; CI: 1.2, 20.6); dyspnea $(\mathrm{OR}=6.0$; CI: 2.1, 17.7); jaundice ( $\mathrm{OR}=12.2$; CI: 4.0, 17.2); HIV/AIDS
$(\mathrm{OR}=21.1 ; \mathrm{CI}: 1.8,251)$ and relative neutrophil count $<10 \%$ (OR 13.2 = ; CI: 1.6, 111.6). Bleeding was not included in the model.

Variables associated with the main syndromes among the survivors

Bacterial infection: pulmonary rales, dyspnea, cough and age $<1$ year-old. Bleeding: edema, dyspnea, palpable lymph nodes, low serum albumin, fever $>30$ days and pulmonary rales. Severe anemia: edema, high BM parasite load, children $<1$ year-old, vomiting, dyspnea and cough. Diarrhea: children $<1$ year-old and vomiting. Palpable spleen was protective. Dyspnea: pulmonary rales, cough, bacterial infection, abnormal X-ray, edema, bleeding and severe anemia. Edema: hemorrhage, severe anemia, dyspnea, hematuria and low serum albumin. Jaundice: increased bilirubin, renal failure and male gender. $B M$ parasite load: neutrophil count $\geq 5,000 / \mathrm{mm}^{3}$, vomiting (low $B M$ parasite load) and severe anemia (high BM parasite load) (Table 5).

\section{Correlation among quantitative data}

Hemoglobin level: negatively correlated with neutrophilia $(\mathrm{r}=-0.15, \mathrm{p}<0.01)$ and slightly with albumin $(\mathrm{r}=-0.21, \mathrm{p}<0.1$, with 72 observations). Liver biochemistry results were all positively correlated: alanine amino transferase (ALT) with bilirrubin $(\mathrm{r}=0.56, \mathrm{p}<0.0001)$ and with alkaline phosphatase $(\mathrm{r}=0.31, \mathrm{p}<0.05)$ and the latter with bilirrubin $(\mathrm{r}=0.36, \mathrm{p}=0.01)$. Renal lesions: alkaline phosphatase correlated with serum creatinine $(\mathrm{r}=0.55, \mathrm{p}<0.001)$ and marginally with proteinuria $(\mathrm{r}=0.31, \mathrm{p}<0.1$, but with only 27 observations $)$, and urinary casts correlated with proteinuria $(\mathrm{r}=0.47, \mathrm{p}<0.0001)$ but not with hematuria. Hematuria was slightly negatively correlated with albumin levels ( $\mathrm{r}=-0.31, \mathrm{p}<0.1$, with 34 observations).

TABLE 3 - Demographic data, clinical syndromes, symptoms, signs and laboratory tests associated with death of patients with visceral leishmaniasis in the univariate analysis.

\begin{tabular}{|c|c|c|c|c|c|}
\hline Variables & $\begin{array}{c}\text { Proportion } \\
\text { among dead } \\
\mathbf{n}(\%)\end{array}$ & $\begin{array}{c}\text { Proportion among } \\
\text { survivors } \\
\text { n(\%) }\end{array}$ & $\begin{array}{c}\text { Odds } \\
\text { ratio }\end{array}$ & $\begin{array}{c}95 \% \\
\text { Confidence } \\
\text { interval }\end{array}$ & $p$ value \\
\hline Age $<1$ year-old & $17 / 76(22.4)$ & $32 / 319(10.0)$ & 3.9 & $2.0-7.8$ & $<0.001$ \\
\hline Age $\geq 40$ years-old & $25 / 76(32.9)$ & $36 / 319(11.3)$ & 5.1 & $2.7-9.6$ & $<0.001$ \\
\hline Malnutrition ${ }^{1}$ & $3 / 5(60.0)$ & $18 / 55(32.7)$ & 3.1 & $0.5-20.1$ & 0.239 \\
\hline Vomiting & $48 / 75(64.0)$ & $89 / 289(30.8)$ & 4.0 & $2.3-6.8$ & $<0.001$ \\
\hline Diarrhea & $61 / 76(80.3)$ & $165 / 320(51.6)$ & 3.8 & $2.1-7.0$ & $<0.001$ \\
\hline Dyspnea & $47 / 76(61.8)$ & $58 / 320(18.1)$ & 7.3 & $4.3-12.6$ & $<0.001$ \\
\hline Edema & $37 / 76(48.7)$ & $62 / 320(19.4)$ & 3.9 & $2.3-6.7$ & $<0.001$ \\
\hline Jaundice & $32 / 76(42.1)$ & $62 / 320(19.4)$ & 3.0 & $1.8-5.2$ & $<0.001$ \\
\hline Pulmonary rales & $23 / 76(30.3)$ & $37 / 220(11.6)$ & 3.3 & $1.8,6.0$ & $<0.001$ \\
\hline Severe anemia ${ }^{2}$ & $28 / 75(37.3)$ & $80 / 315(25.4)$ & 1.8 & $1.0-3.0$ & $<0.05$ \\
\hline Neutrophil count $>5,000 / \mathrm{mm}^{3}$ & $12 / 74(16.2)$ & $16 / 311(5.1)$ & 3.6 & $1.6-7.9$ & $<0.01$ \\
\hline Severe neutropenia ${ }^{3}$ & $6 / 74(8.1)$ & $6 / 311(1.9)$ & 4.5 & $1.4-14.3$ & $<0.05$ \\
\hline Severe thrombocytopenia ${ }^{4}$ & $16 / 24(40.0)$ & $17 / 92(18.5)$ & 2.9 & $1.3-6.7$ & $<0.05$ \\
\hline Liver injury ${ }^{5}$ & $38 / 46(82.6)$ & $63 / 102(61.8)$ & 2.9 & $1.2-7.0$ & $<0.05$ \\
\hline Low seroalbumin ${ }^{6}$ & $21 / 30(70.0)$ & $33 / 73(45.2)$ & 2.8 & $1.1-7.0$ & $<0.05$ \\
\hline Kidney failure $^{7}$ & $18 / 49(36.7)$ & $15 / 85(17.7)$ & 2.7 & $1.2-6.1$ & $<0.05$ \\
\hline Proteinuria & $15 / 26(57.7)$ & $48 / 133(36.1)$ & 2.4 & $1.0-5.7$ & $<0.05$ \\
\hline Higher BM parasite load ${ }^{8}$ & $45 / 55(81.8)$ & $142 / 246(57.7)$ & 3.3 & $1.6-6.8$ & $<0.01$ \\
\hline Previous bleeding events ${ }^{9}$ & $33 / 76(43.4)$ & $40 / 320(12.5)$ & 5.4 & $3.1-9.4$ & $<0.001$ \\
\hline Bacterial infection at admission & $29 / 76(38.2)$ & $62 / 320(19.4)$ & 2.6 & $1.5-4.4$ & $<0.01$ \\
\hline HIV/AIDS & $6 / 76(7.9)$ & $3 / 320(0.9)$ & 9.1 & $2.2-37.1$ & $<0.01$ \\
\hline
\end{tabular}

${ }^{1}$ not significant. See text. ${ }^{2}$ hemoglobin $<7 \mathrm{~g} / 100 \mathrm{~cm}^{3} .{ }^{3}$ percent neutrophil count $<10 \%$. ${ }^{4}$ platelets $<50.000 / \mathrm{mm}^{3} .{ }^{5}$ alanine amino transferase $>$ standard value. ${ }^{6}$ seroalbumin $<3.2 \mathrm{~g} / 100 \mathrm{~cm}^{3} .{ }^{7}$ serum creatinine $>1.2 \mathrm{mg} / 100 \mathrm{~cm}^{3} .{ }^{8}$ amastigotes identified at bone marrow examination. ${ }^{9}$ history of bleeding or the presence of petechiae. 
TABLE 4 - Demographic data, clinical syndromes, symptoms, signs and laboratory tests of patients with visceral leishmaniasis associated with death by suspected bacterial infection and death by bleeding, and the $p$ value of the comparison between the two odds ratios in the univariate analysis.

\begin{tabular}{|c|c|c|c|c|c|c|c|}
\hline \multirow[b]{3}{*}{ Variables } & \multicolumn{3}{|c|}{ Death with suspected bacterial infection } & \multicolumn{3}{|c|}{ Death with bleeding } & \multirow{3}{*}{$\begin{array}{c}\boldsymbol{p} \text { value of the } \\
\text { difference } \\
\text { between the } \\
\text { two OR }\end{array}$} \\
\hline & \multicolumn{3}{|c|}{$95 \%$} & \multicolumn{3}{|c|}{$95 \%$} & \\
\hline & $\begin{array}{l}\text { Odds } \\
\text { ratio }\end{array}$ & $\begin{array}{c}\text { confidence } \\
\text { interval }\end{array}$ & p value & $\begin{array}{l}\text { Odds } \\
\text { ratio }\end{array}$ & $\begin{array}{c}\text { confidence } \\
\text { interval }\end{array}$ & $P$ value & \\
\hline \multicolumn{8}{|c|}{ Variables equally associated to death with bacterial infection and with bleeding } \\
\hline Age $<1$ year-old & 2.9 & $1.1-7.4$ & 0.027 & 5.7 & $2.1-15.2$ & 0.001 & 0.284 \\
\hline Age $\geq 40$ years-old & 2.9 & $1.2-7.2$ & 0.019 & 8.2 & $3.4-19.8$ & $<0.001$ & 0.059 \\
\hline Vomiting & 3.6 & $1.7-7.6$ & 0.001 & 4.7 & $2.1-10.4$ & $<0.001$ & 0.599 \\
\hline Diarrhea & 4.4 & $1.8-10.9$ & 0.001 & 4.1 & $1.6-10.2$ & 0.003 & 0.907 \\
\hline Dyspnea & 8.3 & $3.9-17.7$ & $<0.001$ & 7.5 & $3.5-16.3$ & $<0.001$ & 0.846 \\
\hline Edema & 4.2 & $2.0-8.6$ & $<0.001$ & 4.7 & $2.2-10.0$ & $<0.001$ & 0.791 \\
\hline Previous bleeding ${ }^{1}$ & 4.9 & $2.3-10.5$ & $<0.001$ & 10.2 & $4.7-22.3$ & $<0.001$ & 0.124 \\
\hline HIV/AIDS & 6.6 & $1.1-41.0$ & 0.043 & 10.9 & $2.1-56.6$ & 0.004 & 0.594 \\
\hline Neutrophil count $>70 \%$ & 6.0 & $2.6-13.8$ & $<0.001$ & 3.4 & $1.3-8.8$ & 0.010 & 0.295 \\
\hline \multicolumn{8}{|c|}{ Variables associated only with death by bacterial infection but not with bleeding } \\
\hline Malnutrition & 6.2 & $0.6-63.5$ & 0.126 & 2.1 & $0.12-34.8$ & 0.618 & 0.505 \\
\hline Pulmonary rales & 4.2 & $1.9-9.1$ & $<0.001$ & 2.1 & $0.9-5.3$ & 0.099 & 0.225 \\
\hline Infection at admission ${ }^{2}$ & 5.3 & 2.5-11.0 & $<0.001$ & 1.9 & $0.9-4.2$ & 0.117 & 0.034 \\
\hline Severe anemia ${ }^{3}$ & 2.8 & $1.3-5.7$ & 0.006 & 1.8 & $0.8-3.8$ & 0.144 & 0.346 \\
\hline Neutrophil count $<200 / \mu \mathrm{L}$ & 4.3 & $1.1-17.2$ & 0.037 & 3.7 & $0.9-14.4$ & 0.062 & 0.818 \\
\hline Neutrophil count $>5,000 / \mu \mathrm{L}$ & 5.7 & $2.1-15.3$ & 0.001 & 2.1 & $0.6-7.5$ & 0.274 & 0.136 \\
\hline \multicolumn{8}{|c|}{ Variables associated only with death by bleeding but not with bacterial infection } \\
\hline Jaundice & 2.0 & $0.9-4.3$ & 0.080 & 7.9 & $3.6-17.3$ & $<0.001$ & 0.005 \\
\hline Neutrophil count $<10 \%$ & 4.9 & $0.9-25.8$ & 0.062 & 8.8 & $2.3-33.7$ & 0.001 & 0.519 \\
\hline Severe thrombocytopenia ${ }^{4}$ & 1.4 & $0.3-5.1$ & 0.627 & 8.1 & $2.3-29.9$ & $<0.001$ & 0.011 \\
\hline Liver injury ${ }^{5}$ & 1.2 & $0.3-6.4$ & 0.692 & 12.4 & $1.8-526.0$ & 0.003 & 0.044 \\
\hline Kidney failure ${ }^{6}$ & 0.8 & $0.1-3.4$ & 0.778 & 4.2 & $1.3-13.2$ & 0.004 & 0.022 \\
\hline $\mathrm{BM}_{\text {parasite load }}^{7}$ & 2.2 & $0.8-7.0$ & 0.100 & 2.9 & $1.0-10.3$ & 0.030 & 0.648 \\
\hline
\end{tabular}

${ }^{1}$ History of bleeding or the presence of petechiae. ${ }^{2}$ Clinically suspected. ${ }^{3}$ Hemoglobin $<7 \mathrm{~g} / 100 \mathrm{~cm}^{3} .{ }^{4}$ Platelets $<50.000 / \mathrm{mm}^{3} .{ }^{5}$ Alanine amino transferase $>$ standard value. ${ }^{6} \mathrm{Serum}$ creatinine $>$ $1.2 \mathrm{mg} / 100 \mathrm{~cm}^{3} .{ }^{7}$ Amastigotes identified at bone marrow examination.

TABLE 5 - Clinical and laboratorial variables associated with the main syndromes of visceral leishmaniasis among successfully treated patients. ${ }^{1}$

\begin{tabular}{|c|c|c|c|c|c|c|c|}
\hline Syndromes and variables & $\begin{array}{l}\text { Odds } \\
\text { ratio } \\
\end{array}$ & $\begin{array}{c}\text { 95\% Confidence } \\
\text { interval } \\
\end{array}$ & $p$ value & Syndromes and variables & $\begin{array}{l}\text { Odds } \\
\text { ratio } \\
\end{array}$ & $\begin{array}{c}95 \% \text { Confidence } \\
\text { interval }\end{array}$ & $p$ value \\
\hline Bacterial infection ${ }^{2}$ & & & & Dyspnea & & & \\
\hline Pulmonary rales & 8.9 & $4.0-20.0$ & 0.0000 & Lung rales & 15.8 & $6.8-37.5$ & 0.0000 \\
\hline Dyspnea & 4.6 & $2.3-9.0$ & 0.0000 & Cough & 5.6 & $2.8-11.4$ & 0.0000 \\
\hline Cough & 3.9 & $2.1-7.5$ & 0.0000 & Bacterial infection ${ }^{2}$ & 4.6 & $2.3-9.0$ & 0.0000 \\
\hline Age $<1$ year-old & 2.3 & $0.9-5.3$ & 0.0389 & Abnormal x-ray & 4.5 & $2.2-9.2$ & 0.0000 \\
\hline Bleeding & & & & Edema & 2.8 & $1.4-5.4$ & 0.0013 \\
\hline Edema & 3.9 & $1.8-8.2$ & 0.0001 & Bleeding & 2.9 & $1.3-6.3$ & 0.0031 \\
\hline Dyspnea & 2.9 & $1.3-6.3$ & 0.0031 & Severe anemia ${ }^{4}$ & 2.0 & $1.0-3.8$ & 0.0283 \\
\hline Palpable lymph nodes & 3.0 & $1.1-7.3$ & 0.0092 & Edema & & & \\
\hline Low seroalbumin ${ }^{3}$ & 4.5 & $1.1-21.4$ & 0.0141 & Bleeding & 3.9 & $1.8-8.2$ & 0.0001 \\
\hline Duration of fever $>30$ days & 2.4 & $1.1-5.7$ & 0.0171 & Severe anemia ${ }^{4}$ & 2.8 & $1.5-5.2$ & 0.0006 \\
\hline Pulmonary rales & 2.6 & $1.0-6.3$ & 0.0207 & Dyspnea & 2.8 & $1.4-5.4$ & 0.0013 \\
\hline Severe anemia ${ }^{4}$ & & & & Hematuria $^{5}$ & 3.5 & $0.9-13.2$ & 0.0305 \\
\hline Edema & 2.8 & $1.5-5.2$ & 0.0006 & Low seroalbumin ${ }^{3}$ & 2.8 & $0.9-8.6$ & 0.0370 \\
\hline BM parasite load 5 & 2.4 & $1.2-4.7$ & 0.0051 & Jaundice & & & \\
\hline Age $<1$ year-old & 2.7 & $1.2-6.2$ & 0.0070 & Hyperbilirrubinemia ${ }^{7}$ & 5.3 & $1.7-18.3$ & 0.0011 \\
\hline Vomiting & 2.0 & $1.1-3.7$ & 0.0110 & Renal failure $^{8}$ & 3.3 & $0.9-12.2$ & 0.0351 \\
\hline Dyspnea & 2.0 & $1.0-3.8$ & 0.0283 & Male gender & 2.0 & $1.0-4.1$ & 0.0383 \\
\hline Cough & 1.7 & $1.0-2.9$ & 0.0498 & BM parasite load & & & \\
\hline Diarrhea & & & & Severe anemia ${ }^{4}$ & 2.4 & $1.3-4.7$ & 0.0051 \\
\hline Age $<1$ year-old & 2.5 & $1.1-6.5$ & 0.0207 & Vomiting & 0.46 & $0.25-0.85$ & 0.0072 \\
\hline Vomiting & 1.8 & $1.0-3.0$ & 0.0302 & Neutrophil count $>5,000 / \mathrm{mm}^{3}$ & 0.13 & $0.01-0.60$ & 0.0020 \\
\hline Splenomegaly & 0.2 & $0.02-0.98$ & 0.0248 & & & & \\
\hline
\end{tabular}

${ }^{1}$ Variables are ordered by $p$ values. ${ }^{2}$ Clinically suspected. ${ }^{3}$ Seroalbumin $<3.4 \mathrm{~g} / 100 \mathrm{~cm}^{3} .{ }^{4}$ Hemoglobin $<7 \mathrm{~g} / 100 \mathrm{~cm}^{3} .{ }^{5}$ Amastigotes identified at bone marrow examination. ${ }^{6} \mathrm{Mycroscopic}$ hematuria ${ }^{7}$ Total bilirrubin $>1.2 \mathrm{mg} / 100 \mathrm{~cm}^{3} .{ }^{8}$ Serum creatinine $>1.2 \mathrm{mg} / 100 \mathrm{~cm}^{3}$. 


\section{DISCUSSION}

Age and comorbidities, but not sex, were relevant to death by VL in this study. Children $<1$ year-old and adults aged over 40 yearsold were at an increased risk of death. Analysis of patient medical records revealed that surviving very young children had a higher risk of bacterial infections, diarrhea and severe anemia; these findings may be relevant for therapeutic considerations. Analysis also revealed more males with jaundice. Malnutrition also was not significantly associated with death in general, but it showed a remarkable effect on death by bacterial infection, though not on bleeding. Despite the small number of patients with HIV infection, it was a serious threat to the survival of patients with VL. However, it was not clear why coinfection increases fatality: whether it worsens the risks associated with the disease itself or if it leads to death by other opportunistic infections. In any case, the data indicate that patients with VL should be routinely tested for HIV and special attention should be provided for those infected.

Aside from bacterial infections and bleeding manifestations, several distinct clinical syndromes were indicative of death: a digestive syndrome composed of vomiting and diarrhea; a respiratory syndrome with rales and dyspnea; an edematous syndrome; a hepatic syndrome with jaundice and alterations in liver enzymes, a renal syndrome with failure and proteinuria; a complex hematologic syndrome with bipolar associations of neutrophils, anemia, thrombocytopenia and hemorrhages; and an immune suppressive syndrome with opportunistic bacterial infections and high BM parasite load. Therefore, the key question is to determine whether any common denominator exists in this spectrum of events that could serve as the target for interventions to reduce lethality by VL.

Bacterial infections and bleeding were the two most prominent outcomes associated with death by VL. Among the variables determined as connected with death solely by bacterial infection, anemia, pulmonary rales and neutrophilia were merely signs of current infection. Therefore, aside from infrequent severe neutropenia, there was no clinical clue predicting or explaining susceptibility to bacterial infections. However, similar to that which occurs in sepsis ${ }^{12}$, generalized cytokine-mediated immune paralysis could also occur in $\mathrm{VL}$ and this hypothesis should be investigated. In contrast, since other variables were determined to be associated with death by both infection and bleeding, the data seem to suggest that immune suppression coexists with inflammation, with the balance between them determining patient outcome: immune paralysis or severe inflammation. On the other hand, the association of certain variables only with bleeding provides support for the idea that hemorrhaging is part of the expression of a systemic inflammatory response. Thrombocytopenia may be only an adjuvant factor for bleeding in VL and not its cause, since it seldom reached levels that would trigger bleeding on its own; indeed, platelet count has been shown to be inversely correlated with megakaryocytic hyperplasia in the bone marrow ${ }^{13}$, which denotes consumption. The apparent cause of bleeding is disseminated intravascular coagulation (DIC), as previously described in $\mathrm{VL}^{10}$. It is likely that DIC follows the same pathway as in sepsis: inflammation causes DIC by activation of coagulation and fibrinolysis triggered by the proinflammatory response $\mathrm{e}^{14}$.

The hematological data were the most complex to interpret. Analysis showed that severe anemia was associated with higher BM parasite load and that it predicted death by bacterial infection but not by bleeding. Moreover, it was related to inflammatory signs, such as vomiting, edema and lung inflammation, suggesting that bacterial infections and increasing parasite load might trigger anemia via inflammation. Finally, it seems that bleeding was actually not the cause of anemia in VL, because most patients with anemia did not present hemorrhagic events. Even modest neutrophilia and extreme neutropenia were determined to be associated with lethal infections, together with severe anemia, which suggests that a prompt search for infection should be conducted and empirical antibiotic usage should be considered in patients with these blood counts. However, since severe relative neutropenia was also strongly associated with bleeding, neutropenia may be a consequence of inflammation. The contrast of BM hypercellularity with neutropenia observed in patients with $\mathrm{VL}^{15}$ suggests that neutrophils are produced and then sequestered from the peripheral circulation. Lastly, higher numbers of neutrophils apparently reduced the BM parasite load.

Analysis of other syndromes that composed the clinical picture of severe VL also offered interesting insights. The association of edema with severe VL might be a consequence of three mechanisms acting together: a) capillary leakage due to systemic endothelial activation; b) low oncotic pressure due to low serum albumin, a feature of acute phase reaction observed in VL; and c) increased hydrostatic pressure led by glomerulonephritis, as detected by hematuria. Analysis verified that serum creatinine was a risk factor only for death by bleeding and that it was correlated with elevated alkaline phosphatase, suggesting the presence of interstitial nephritis, as previously described ${ }^{16}$, and that it is part of the general inflammation status. Moreover, the presence of proteinuria should alert clinicians to the additional risk of glomerulonephritis to previously established interstitial nephritis. Dyspnea was associated with lethal bacterial infections and bleeding. Respiratory injury was demonstrated by the presence of lung sounds, coughing and x-ray infiltrates. The association with bleeding and edema, evidence of inflammation, suggests that acute respiratory distress syndrome following interstitial pneumonia occurs in severe human $\mathrm{VL}^{17}$. The questions that arise from the association of liver involvement with patients who died from bleeding include why hepatitis occurs in VL and what the nature of its relationship with hemorrhaging is. Since no hepatocyte parasitism occurs in $\mathrm{VL}^{18}$, pathogenesis is probably also due to inflammation. The relationship with bleeding might give the impression that absolute liver failure is frequent in VL. However, although hepatitis is common in VL, death by fulminant hepatitis is unusual ${ }^{19}$. Thus, the role of the liver in bleeding in VL is probably restricted to a relative deficiency of coagulation factors during established DIC. Finally, analysis of the data showed that diarrhea and vomiting are interconnected. Of note is the negative association of splenomegaly with diarrhea.

Certain other findings offer additional clues concerning the evolution of severe disease. Interestingly, BM parasite load was associated with fatal bleeding and severe anemia. Additionally, the longer the disease was active, the more the survivors bled, which is an indication of progressive inflammation in VL. This last finding indicates that bacterial infections follow a different pathogenic pathway compared to bleeding, though leading to it, and that negative feedback mediators might exist that oppose the two outcomes.

Some weaknesses concerning data collection in this retrospective hospital-based case-control study should be highlighted: the quality of data recorded on medical charts may not have been uniform throughout the study period; bacterial infections were diagnosed by clinical suspicion as a result of early antibiotic usage; BM parasite 
load was coded as a binary variable. However, these problems mostly likely led only to random misclassification bias, which may actually have contributed to underestimate some of the associations.

This diversity of pathogenic associations with VL severity is the most striking result of this study. These findings are similar to sepsis and malaria, suggesting the same underlying mechanism, which is systemic inflammatory response with multiorgan failure ${ }^{20}$. The main difference is time; while these are acute diseases, VL develops over a protracted course and possibly because of this, patients do not present with acute hemodynamic changes. L. chagasi is an intracellular parasite restricted to the macrophage lineage, dendritic cells, neutrophils, eosinophils and fibroblasts ${ }^{21}$, no parasitism of hepatocytes, pneumocytes, glomerular or tubular cells or epithelial or glandular intestinal cells occurs ${ }^{17,18,22,23}$, and no toxins are released by Leishmania. Therefore, the absence of parasite actions or products that would harm the host cells or tissues is one more indication that the systemic pathogenicity of VL is dependent on the host response. Although inflammatory tests were not evaluated in this study, inflammation is an ordinary feature of $\mathrm{VL}$, as indicated by increases in erythrocyte sedimentation rate and acute phase proteins $\mathrm{s}^{24-26}$. Moreover, the proinflammatory cytokines interferon- $\gamma$, TNF and IL- 6 and the chemokine IL- 8 are elevated in VL as part of a broad and sustained innate response $\mathrm{e}^{27,32,33}$. Indeed, the clinical actions of these cytokines in humans fit very well with the status seen in VL in this study: wasting, vomiting, fever, thrombocytopenia, diarrhea, hepatotoxicity, coagulopathy, alterations in leukocyte trafficking and release and acute phase response $\mathrm{e}^{34-37}$. Therefore, the hypothesis that these cytokines mediate the pathogenesis of severe VL is very consistent and should be considered for future investigations.

\section{ACKNOWLEDGMENTS}

The authors would like to thank Dr. Jay M. Stewart for kindly reviewing the article. The study was supported by the Natan Portella Tropical Diseases Institute, who provided assistance and materials for data collection.

\section{CONFLICT OF INTEREST}

The authors declare that there is no conflict of interest.

\section{FINANCIAL SUPPORT}

CNPq - Conselho Nacional de Desenvolvimento Científico e Tecnológico.

\section{REFERENCES}

1. Herwaldt BL. Leishmaniasis. Lancet 1999; 354:1191-1199.

2. Seaman J, Mercer AJ, Sondorp HE, Herwaldt BL. Epidemic visceral leishmaniasis in southern Sudan: treatment of severely debilitated patients under wartime conditions and with limited resources. Ann Intern Med 1996; 124:664-672.

3. Série histórica de óbitos e casos de doenças de notificação compulsória no Brasil (1980-2005): Departamento de Vigilância Epidemiológica. Coordenação Geral de Vigilância Epidemiológica. Secretaria de Vigilância em Saúde. Brasília; Ministério da Saúde; 2006.

4. Leishmaniose Visceral Grave: Normas e Condutas. Departamento de Vigilância Epidemiológica. Coordenação Geral de Vigilância Epidemiológica; Secretaria de Vigilância em Saúde. Brasília. Ministério da Saúde; 2006.
5. Werneck GL, Batista MS, Gomes JR, Costa DL, Costa CH. Prognostic factors for death from visceral leishmaniasis in Teresina, Brazil. Infection 2003 31:174-177

6. Abdelmoula MS, M'hamdi Z, Amri F, Tebib N, Ben Turkia H, Ben Dridi MF La leishmaniose viscerale chez l'enfant: facteurs pronostiques. Tunis Med 2003; 81:535-539.

7. Collin S DR, Ritmeijer K, Keus K, Melaku Y, Kipngetich S, Davies C. Conflict and kala-azar: determinants of adverse outcomes of kala-azar among patients in southern Sudan. Clin Infect Dis 2004; 38:612-619.

8. Andrade TM, Carvalho EM Rocha H. Bacterial infections in patients with visceral leishmaniasis. J Infect Dis 1990; 162:1354-1359.

9. Queiroz MJ, Alves JG, Correia JB. Visceral leishmaniasis: clinical and epidemiological features of children in an endemic area. J Pediatr 2004; 80:141-146.

10. Lomtadze ML, Khochava MA, Shalamberidze IA, Kharaishvili VI, Vorob'eva EO [Study of intravascular coagulation activation markers in patients with visceral leishmaniasis]. Georgian Med News; 2005. p. 47-50.

11. Baranwal AK, Mandal RN, Singh R. Fulminant hepatic failure complicating visceral leishmaniasis in an apparently immunocompetent child. Indian J Pediatr 2007; 74:489-491.

12. Hietbrink F, Koenderman L, Rijkers G, Leenen L. Trauma: the role of the innate immune system. World J Emerg Surg 2006; 1:15.

13. Marwaha N, Sarode R, Gupta RK, Garewal G, Dash S. Clinico-hematological characteristics in patients with kala azar. A study from north-west India Trop Geogr Med 1991; 43:357-362.

14. Esmon CT. The impact of the inflammatory response on coagulation. Thromb Res. 2004; 114:321-327.

15. Al-Jurayyan NA, Al-Nasser MN, Al-Fawaz IM, Al Ayed IH, Al Herbish AS, AlMazrou AM, et al. The haematological manifestations of visceral leishmaniasis in infancy and childhood. J Trop Pediatr 1995; 41:143-148.

16. Dutra M, Martinelli R, Carvalho EM, Rodrigues LE, Brito E, Rocha H. Renal involvement in visceral leishmaniasis. Am J Kidney Dis 1985; 6:22-27.

17. Duarte MI, Matta VL, Corbett CE, Laurenti MD, Chebabo R, Goto H. Interstitial pneumonitis in human visceral leishmaniasis. Trans Rev Soc Trop Med Hyg $1989 ; 83: 73-76$

18. El Hag IA, Hashim FA, El Toum IA, Homeida M, El Kalifa M, El Hassan AM Liver morphology and function in visceral leishmaniasis (Kala-azar). J Clin Pathol 1994; 47: 547-551.

19. Duarte MI, Corbett CE. Histopathological patterns of the liver involvement in visceral leishmaniasis. Rev Inst Med Trop Sao Paulo 1987; 29:131-136.

20. Remick DG. Pathophysiology of sepsis. Am J Pathol 2007; 170:1435-1444.

21. Garg R, Trudel N, Tremblay MJ. Consequences of the natural propensity of Leishmania and HIV-1 to target dendritic cells. Trends Parasitol 2007; 23:317-324.

22. Duarte MI, Silva MR, Goto H, Nicodemo EL, Amato V. Interstitial nephritis in human kala-azar. Trans R Soc Trop Med Hyg 1983; 77:531-537.

23. Alonso MJ, Munoz E, Picazo A, Abad MM, Gomez F, Roldan M, et al. Duodenal leishmaniasis diagnosed by biopsy in two HIV-positive patients. Pathol Res Pract 1997; 193:43-47.

24. Thakur CP, Singh RK, Hassan SM, Kumar R, Narain S, Kumar A. Amphotericin B deoxycholate treatment of visceral leishmaniasis with newer modes of administration and precautions: a study of 938 cases. Trans R Soc Trop Med Hyg 1999; 93:319-323.

25. Wasunna KM, Raynes JG, Were JB, Muigai R, Sherwood J, Gachihi G, et al. Acute phase protein concentrations predict parasite clearance rate during therapy for visceral leishmaniasis. Trans R Soc Trop Med Hyg 1995; 89:678-681.

26. Alonso DP, Ferreira AF, Ribolla PE, Santos IK, Cruz M, Carvalho F, et al. Genotypes of the mannan-binding lectin gene and susceptibility to visceral leishmaniasis and clinical complications. J Infect Dis 2007; 195:1212-1217.

27. Peruhype-Magalhaes V, Martins-Filho OA, Prata A, Silva LA, Rabello A, TeixeiraCarvalho A, et al. Mixed inflammatory/regulatory cytokine profile marked by simultaneous raise of interferon-gamma and interleukin-10 and low frequency of tumour necrosis factor-alpha+ monocytes are hallmarks of active human visceral Leishmaniasis due to Leishmania chagasi infection. Clin Exp Immunol 2006; 146:124-132. 
28. Ansari NA, Saluja S, Salotra P. Elevated levels of interferon-gamma, interleukin-10, and interleukin-6 during active disease in Indian kala azar. Clin Immunol 2006; 119:339-345.

29. Lagler H, Willheim M, Traunmuller F, Wahl K, Winkler H, Ramharter M, et al. Cellular profile of cytokine production in a patient with visceral leishmaniasis: gammadelta $+\mathrm{T}$ cells express both type 1 cytokines and interleukin-10. Scand J Immunol 2003; 57:291-295.

30. Van Der Poll T, Zijlstra EE, Mevissen M. Interleukin 6 during active visceral leishmaniasis and after treatment. Clin Immunol Immunopathol 1995; 77:111114.

31. Caldas A, Favali C, Aquino D, Vinhas V, Van Weyenbergh J, Brodskyn C, et al. Balance of IL-10 and interferon-gamma plasma levels in human visceral leishmaniasis: implications in the pathogenesis. BMC Infect Dis 2005; 5:113.

32. Nylen S, Maurya R, Eidsmo L, Manandhar KD, Sundar S, Sacks D. Splenic accumulation of IL-10 mRNA in T cells distinct from CD4+CD25+ (Foxp3) regulatory T cells in human visceral leishmaniasis. J Exp Med 2007; 204:805-817.

33. Weigand MA, Horner C, Bardenheuer HJ, Bouchon A. The systemic inflammatory response syndrome. Best Pract Res Clin Anaesthesiol 2004; 18:455-475.

34. Clark IA. How TNF was recognized as a key mechanism of disease. Cytokine Growth Factor Rev 2007; 18:335-343.

35. Schroder K, Hertzog PJ, RavasiT, Hume DA. Interferon-gamma: an overview of signals, mechanisms and functions. J Leukoc Biol 2004; 75:163-189.

36. Gabay C. Interleukin-6 and chronic inflammation. Arthritis Res Ther 2006; 8(supl 2): S3.

37. Remick DG. Interleukin-8. Crit Care Med 2005; 33:S466-467. 